\title{
ANALISIS PENGGUNAAN KOHESI GRAMATIKAL DALAM TEKS EKSPOSISI SISWA KELAS X SMK BINA BUDI LUHUR BOGOR
}

\author{
Ulfiana $^{\left.\mathrm{a}^{*}\right)}$, Stella Talitha ${ }^{\text {a)}}$, Tri Mahajani a) \\ a) Universitas Pakuan, Kota Bogor, Indonesia \\ ${ }^{*}$ e-mail korespondensi: anaulfi320@gmail.com
}

\section{Riwayat Artikel}

diterima 04 Juni 2021 direvisi 25 Juni 2021

disetujui 28 Juli 2021

\begin{abstract}
Abstrak.
Penelitian ini bertujuan untuk mendeskripsikan penggunaan jenis kohesi gramatikal dalam teks eksposisi siswa kelas X SMK Bina Budi Luhur Bogor, serta untuk mengetahui penggunaan jenis kohesi gramatikal yang paling dominan pada teks eksposisi siswa. Metode yang digunakan dalam penelitian ini, yaitu metode deskriptif kualitatif. Sumber data penelitian ini teks ekposisi siswa kelas X SMK Bina Budi Luhur Bogor. Teknik pengumpulan data yang digunakan dalam penelitian ini adalah studi pustaka. Pengecekan keabsahan data dalam penelitian ini menggunakan triangulasi. Jenis kohesi gramatikal yang menjadi fokus penelitian, yaitu referensi endoforis, referensi eksoforis, konjungtor, substitusi, dan elipsis. Dari hasil analisis tersebut ditemukan penggunaan kohesi gramatikal sebanyak 150 data. Adapun jumlah temuan yang pertama ialah penggunaan referensi endoforis dengan total 44 temuan (29\%). Kedua, penggunaan kohesi gramatikal berupa referensi eksoforis dengan total 25 temuan (17\%). Referensi eksoforis berkaitan dan mengacu pada acuan sesuatu yang berada di luar teks. Ketiga, penggunaan kohesi gramatikal berupa konjungtor dengan total 60 temuan $(40 \%)$. Keempat, penggunaan kohesi gramatikal berupa substitusi dengan total 14 temuan $(9 \%)$. Substitusi berkaitan dengan pergantian suatu unsur bahasa oleh unsur lain dalam satuan yang lebih besar. Terakhir, penggunaan kohesi gramatikal berupa elipsis dengan total 7 temuan (5\%). Dengan demikian, jumlah tersebut dapat disimpulkan bahwa dalam teks eksposisi siswa ditemukan banyak penggunaan kohesi gramatikal. Adapun dari temuan data 30 teks eksposisi ditemukan jumlah sebanyak 150 data dan penggunaan alat kohesi gramatikal, yang paling dominan terdapat pada penggunaan kohesi gramatikal berupa konjungtor dengan temuan data 60 kutipan dengan presentase $40 \%$.
\end{abstract}

Kata Kunci: Kohesi Gramatikal; Text Eksposisi

\section{ANALYSIS OF THE USE OF GRAMMATICAL COHESION IN EXPOSITION TEXT FOR CLASS X STUDENTS AT SMK BINA BUDI LUHUR BOGOR}

\begin{abstract}
This study aims to describe the use of grammatical cohesion types in the exposition texts of class X students of SMK Bina Budi Luhur Bogor, as well as to find out the use of the and to most dominant type of grammatical cohesion in students' exposition texts. The method used in this research is qualitative descriptive method. The data source of this research is the exposition text of class $\mathrm{X}$ students of SMK Bina Budi Luhur Bogor. The data collection technique used in this research is literature study. Checking the validity of the data in this study using triangulation. The types of grammatical cohesion that are the focus of this research are endophoric references, exophoric references, conjunctions, substitutions, and ellipsis. From the results of the analysis found the use of grammatical cohesion as much as 150 data. The first number of findings is the use of endophoric references with a total of 44 findings (29\%). Second, the use of grammatical cohesion in the form of exophoric references with a total of 25 findings (17\%). Exophoric references are related to and refer to references to something that is outside the text. Third, the use of grammatical cohesion in the form of conjunctors with a total of 60 findings $(40 \%)$. Fourth, the use of grammatical cohesion in the form of substitution with a total of 14 findings (9\%). Substitution is related to the replacement of an element of language by another element in a larger unit. Finally, the use of grammatical cohesion in the form of ellipsis with a total of 7 findings (5\%). Thus, it can be concluded that in the students' exposition texts, there are many uses of grammatical cohesion. As for the data findings of 30 exposition texts, it was found that there were 150 data and the use of grammatical cohesion tools, the most dominant of which was the use of grammatical cohesion in the form of conjunctors with data findings of 60 quotes with a percentage of $40 \%$.
\end{abstract}

Keywords: Keywords: Grammatical cohesion and exposition text.

\section{PENDAHULUAN}

Menulis merupakan salah satu komponen dalam keterampilan berbahasa, selain keterampilan membaca, menyimak, dan berbicara. Keempat komponen ini memiliki keterkaitan sehingga tidak dapat dipisahkan antara satu dengan yang lainnya. Untuk menguasai keterampilan menulis yang baik, siswa harus menguasai keterampilan membaca, lalu keterampilan menyimak, dan keterampilan berbicara sehingga menjadi rangkaian bahasa tulis yang teratur, sistematis, dan logis. Hal ini tentunya bukan merupakan pekerjaan yang mudah, melainkan memerlukan latihan terusmenerus. 
Belajar menulis dapat melatih siswa untuk kreatif mengolah kata dari pengalamannya yang sudah dirasakan. Dalam pembelajaran bahasa Indonesia, materi keterampilan menulis sudah diberikan sejak pendidikan sekolah dasar hingga perguruan tinggi. Nantinya siswa dapat terus belajar dalam meningkatkan keterampilan menulis, melalui pembelajaran bahasa Indonesia di kelas. Dalam pembelajaran bahasa Indonesia keterampilan menulis tersebut terdapat dalam silabus mata pelajaran bahasa Indonesia jenjang SMA/MAN/SMK termuat dalam banyak teks yang kemudian dijadikan materi pembelajaran, salah satu teks tersebut adalah teks eksposisi.

Melalui tulisan yang baik akan memberikan kemudahan bagi pembaca dalam memahami maksud atau pesan yang akan disampaikan penulis. Selain itu, suatu teks yang baik adalah teks yang apabila dilihat dari segi hubungan bentuk dan strukturnya bersifat kohesif dan dilihat dari segi hubungan makna atau struktur batinnya bersifat koheren. Teks tersebut dapat dikatakan utuh apabila kalimat-kalimat di dalamnya mendukung satu topik yang sedang dibahas, sedangkan wacana dikatakan baik apabila kalimat-kalimatnya disusun secara teratur dan sistematis sehingga menunjukkan keruntutan gagasan yang akan diungkapkan melalui penanda kekohesian. Di dalam masyarakat, kehadiran wacana dapat dipahami dengan baik oleh responden melalui teks. Oleh karena itu, peneliti berpendapat bahwa kesatuan wacana akan menjadi padu dan sesuai jika terdapat penggunaan fungsi elemen kohesi sebagai pendukungnya.

Kohesi merupakan konsep semantik yang merujuk kepada perkaitan bentuk kebahasaan yang didapati pada suatu ujaran yang membentuk wacana. Hal ini berarti bahwa hubungan makna, kohesi gramatikal memperlihatkan jalinan ujaran dalam bentuk kalimat untuk membentuk teks atau konteks. Kohesi gramatikal tersebut tediri dari referensi, konjungtor, substitusi, dan pelesapan (elipsis). Oleh karena itu, melalui sebuah teks seseorang juga dapat menyampaikan yang ingin mereka sampaikan.

Aspek yang membentuk kohesi di dalam teks harus jelas dan tepat mendukung koherensi. Apabila urutan di dalam teks tidak jelas maka akan menyebabkan tidak koheren. Hubungan kohesi diciptakan atas dasar aspek gramatikal dengan pilihan kata yang serasi, hubungan makna antarkalimat dalam sebuah teks, seperti sebuah teks eksposisi yang harus mempunyai sebuah kesatuan baik tanggapan maupun pengembangan. Kesatuan dan tanggapan ditimbulkan oleh kalimat-kalimat yang mendukung dalam teks eksposisi tersebut. Dengan demikian, teks eksposisi tersebut akan menjadi teks yang mudah dipahami dan diterima pembaca.

Di dalam teks eksposisi banyak berisi kohesi gramatikal sehingga peneliti tertarik untuk melakukan penelitian pada teks eksposisi siswa kelas X SMK Bina Budi Luhur Bogor tentang jenis kohesi gramatikal.

Berdasarkan latar belakang masalah di atas maka fokus permasalahan dalam penelitian ini adalah jenis kohesi gramatikal yang terdapat dalam teks eksposisi siswa kelas $\mathrm{X}$ SMK Bina Budi Luhur Bogor.
Jenis kohesi gramatikal dibatasi pada kohesi yang berupa referensi, konjungtor, substitusi, dan pelesapan (elipsis) pada teks eksposisi siswa kelas X SMK Bina Budi Luhur Bogor.

\section{METODE PENELITIAN}

Penelitian ini mengkaji tentang kepaduan wacana dari aspek gramatikalnya. Berdasarkan hal tersebut maka penelitian ini merupakan penelitian deskriptif kualitatif. Penelitian deskriptif adalah penelitian yang dilakukan berdasarkan pada fakta yang ada atau fenomena secara empiris hidup pada penutur-penuturnya. Penelitian ini mengeksplorasi, mendeskripsikan dan mengeksplanasi suatu variabel, gejala, atau keadaan secara sistematis, faktual dan akurat mengenai data, sifat-sifat serta hubungan fenomena yang diteliti.

Metode deskripsi kualitatif adalah pendekatan yang lebih menandai pada hasil penelitian yang bersangkutan dengan bahasa dengan cara menandai cara penggunaan bahasa tahap demi tahap, langkah demi langkah. Adapun pendekatan kualitatif berkaitan dengan data yang tidak berupa angka-angka, tetapi berupa bentuk bahasa. Metode penelitian kualitatif adalah metode yang bermaksud untuk memahami suatu fenomena tentang apayang dialami oleh subjek penelitian misalnya perilaku, persepsi, motivasi, tindakan, dan lain-lain secara holistik, dan dengan cara deskripsi dalam bentuk kata-kata dan bahasapada suatu konteks khusus yang alamiah (Moleong, 2013:6).

Menurut Arikunto (2010:3) metode deskripsi kualitatif adalah metode penelitian yang dimaksudkan untuk menyelidiki suatu keadaan dan kondisi yang hasilnya akan dipaparkan dalam bentuk laporan penelitian. Pendekatan kualitatif yang digunakan dalam penelitian ini sebagai prosedur dalam memecahkan masalah yang sedang diteliti dengan cara mendeskripsikan atau menggambarkan masalah. Deskripsi masalah terhadap objek penelitian yan $g$ dipilih didasarkan pada fakta-fakta apa adanya.

Berdasarkan pendapat para ahli di atas, dapat disimpulkan bahwa metode deskriptif kualitatif merupakan metode yang bermaksud memahami dan menggambarkan suatu hal kejadian nyata berupa fakta-fakta yang ada. Sebagai sebuah penelitian kualitatis, data dalam penelitian ini berupa wacana yang terdapat dalam sumber data. Hasil penelitian berupa kutipan-kutipan data untuk memberi gambaran.

\section{HASIL DAN PEMBAHASAN}

\section{A. Wacana}

Wacana merupakan satuan bahasa yang terlengkap dan tertinggi atau terbesar di atas kalimat dengan koherensi dan kohesi tinggi yang berkesinambungan yang mempunyai awal dan akhir yang nyata disampaikan secara lisan atau tertulis (Sumarlam, 2009:7).

Yuwono (2005:92) berpendapat bahwa wacana adalah kesatuan makna (semantik) antarbagian di dalam suatu bangun bahasa. Sebagai kesatuan makna, wacana dilihat sebagai bangun bahasa yang utuh karena setiap bagian di dalam wacana itu berhubungan secara padu. 
Dari pendapat kedua pakar di atas dapat disimpulkan bahwa wacana mempunyai ikatan yang berkesinambungan dari unsur koherensi maupun kohesi, dan yang di dalamnya memiliki perkumpulan bahasa di atas kalimat dan klausa itu artinya wacana lebih besar dari pada kalimat dan klausa. Teks yang ada dalam sebuah wacana itu berupa kalimat dan klausa yang ditulis. Wacana yang lengkap memiliki gagasan, konsep, pikiran dan ide yang utuh sehingga dapat dipahami oleh pembaca. Wacana juga harus mempunyai unsur kohesi dan koherensi agar nantinya wacana tersebut menjadi padu dan utuh sehingga dapat menjadi wacana yang sempurna. Wacana juga bangun bahasa yang utuh dan setiap bagian di dalam wacana itu saling berhubungan dan padu.

Wacana memuat rentetan kalimat yang berkaitan, yang mengubungkan proposisi yang satu dengan proposisi yang lainnya, membentuk satu kesatuan di dalam makna (Moeliono, dkk. 2015:419). Berdasarkan pernyataan tersebut, dapat diartikan bahwa rentetan kalimat itu membawa proposisi dan proposisi tersebut saling berkaitan sehingga membentuk satu kesatuan proposisi. Proposisi yang dimaksudnya adalah sebuah informasi, wacana sebagai rentetan kalimat yang memiliki keterkaitan sehingga nantinya menghubungkan informasi satu dengan yang lainnya.

Wacana juga merupakan satuan bahasa yang lengkap, yaitu dalam hierarki gramatikal merupakan satuan gramatikal tertinggi atau terbesar, wacana ini direalisasikan dalam bentuk karangan yang utuh (novel, buku, seri ensiklopedia, dan sebagainya), paragraf, kalimat atau kata yang membawa amanat yang lengkap (Kridalaksana dalam Arifin, dkk., 2018:179). Berdasarkan pendapat tersebut, wacana merupakan satuan bahasa yang lengkap dan terbesar, karena wacana dapat direalisasikan dalam bentuk karangan yang utuh atau lengkap. Artinya wacana sebagai satuan bahasa yang tertinggi karena setelah wacana terdapat kalimat, kata, klausa, frasa, dan morfem.

Dari beberapa pendapat di atas dapat disimpulkan bahwa wacana merupakan satuan bahasa yang terlengkap dan tertinggi. Wacana mempunyai ikatan yang berkesinambungan dari unsur koherensi maupun kohesi, dan yang di dalamnya memiliki perkumpulan bahasa di atas kalimat dan klausa itu artinya wacana lebih besar dari pada kalimat dan klausa. Wacana memuat rentetan kalimat yang berhubungan, yang mengubungkan proposisi yang satu dengan proposisi yang lainnya, membentuk satu kesatuan informasi, proposisi yang dimaksud ialah sebuah informasi.

\section{B. Kohesi}

Kohesi merupakan kepaduan bentuk bahasa yang secara struktural membentuk ikatan sintaksis. Kohesi dapat dibagi menjadi kohesi gramatikal yang terdiri atas referensi, substitusi, elipsis dan konjungtor dan kohesi leksikal yaitu reiterasi dan kolokasi (Halliday dan Hassan dalam Arifin, dkk., 2018:46).

Kohesi juga satuan semantis yang direalisasikan ke dalam tiga tataran sistem bahasa yaitu sistem semantis atau makna, sistem leksikogramatikal atau bentuk, dan sistem fonologis dan morfologis. Kohesi atau kepaduan wacana menurut aspek formal bahasa dalam sebuah wacana (Tarigan, 2009:96).
Kohesi adalah kepaduan bentuk yang secara struktural membentuk ikatan sintaktikal (Mulyana, 2005:26). Berdasarkan pengertian tersebut, kohesi menjadi sangat penting dalam sebuah wacana, konsep dari kohesi sendiri mengacu kepada kepaduan bentuk yang membuat wacana menjadi saling terkait, kohesi dalam wacana diartikan sebagai kepaduan bentuk yang membentuk ikatan sintaktikal. Dengan begitu wacana akan lebih terlihat padu dengan tatanan yang jelas, wacana juga akan mudah dipahami dengan kohesi yang baik. Dalam sebuah wacana kepaduan merupakan poin yang penting, dimana kohesi dapat membuat pemahaman pembaca lebih mudah. Dari beberapa pakar ahli di atas bahwasanya kohesi merupakan kepaduan bentuk bahasa yang secara struktural membentuk ikatan sintaksis.Dengan menggunakan konsep kohesi untuk menunjukkan hubungan formal bentuk antar kalimat yang satu dengan kalimat yang lainnya. Konsep dari kohesi sendiri mengacu kepada kepaduan bentuk yang membuat wacana menjadi saling terkait. Dan lagi keserasian hubungan antar unsur wacana satu dengan yang lainnya, dapat dipahami secara logis dan tidak jauh dari makna yang sebenarnya.

\section{Kohesi Gramatikal}

Kohesi gramatikal adalah perpaduan wacana dari segi bentuk atau struktur lahir wacana (Sumarlam, 2010:40). Kohesi merupakan satu set kemungkinan yang terdapat dalam bahasa untuk menjadikan teks menjadi satu kesatuan. Kohesi dapat dibagi menjadi kohesi gramatikal yang terdiri atas referensi, substitusi, elipsis, dan konjungtor dan kohesi leksikal terdiri atas reiterasi dan kolokasi Kohesi termasuk kelompok unsur internal struktur wacana, sedangkan koherensi termasuk kelompok unsur eksternal struktur wacana.

Arifin, dkk (2018:26) berpendapat bahwa kohesi gramatikal digunakan untuk menunjukkan adanya hubungan bentuk (bahasa) di antara kalimat pembangun wacana. Kohesi gramatikal terdiri atas referensi, substitusi, elipsis, dan relasi konjungtif, kemudian untuk menentukan sifat relasi dapat dilakukan dengan mempertimbangkan hubungannya dengan unsur lingual dan ekstalingual wacana.

Kohesi gramatikal berkaitan dengan unsur gramatikal dengan menghadirkan unsur gramatikal itu sendiri (Zaimar dan Harahap, 2015:135). Berdasarkan pernyataan tersebut, makna teks tergantung pada hubungan antar bagian pembangun teks, bukan salah satu bagian saja. Unsur gramatikal merupakan salah satu unsur yang penting untuk menangkap makna suatu wacana.

Dari beberapa pendapat pakar di atas, dapat disimpulkan bahwa kohesi gramatikal ialah hubungan sistematis antar unsur bahasa yang digunakan dalam kaitannya dengan tata bahasa. Terbentuknya suatu hubungan bahasa dalam wacana disebabkan adanya kohesi gramatikal, jelas bahwa kohesi gramatikal termasuk dalam bagian penting demi membentuk makna utuh sebuah wacana. Wacana yang baik adalah wacana yang memiliki hubungan antar unsur pembentuknya, unsur yang dimaksud adalah berupa bahasa yang digunakan agar padu dan utuh. Jadi makna teks tergantung pada hubungan antar bagian pembangun teks tersebut, bukan salah satu bagian saja. Kohesi gramatikal 
terdiri atas referensi, substitusi, dan relasi konjungtor. Penentuan penggunaan alat kohesi gramatikal serta penentuan sifat relasi dilakukan dengan mempertimbangkan hubungannya dengan unsur lingual dan insur ekstralingualnya dalam wacana. Alat kohesi gramatikal sendiri mempunyai empat macam yaitu:

\section{1) Referensi atau Pengacuan}

Referensi (pengacuan) adalah salah satu jenis kohesi gramatikal yang berupa satuan lingual lain (atau suatu acuan) yang mendahului atau mengikutinya (Sumarlan, 2009:23). Berdasarkan pendapat tersebut dapat dinyatakan bahwa referensi atau pengacuan terdapat di dalam atau pada bagian kohesi gramatikal yang tentunya berhubungan dengan penggunaan kelompok kata atau kalimat di dalam sebuah wacana. Pengacuan referensi adalah salah satu jenis kohesi gramatikal yang berupa satuan lingual tertentu yang mengacu pada satuan lingual lain atau satu acuan yang mendahului dan mengikutinya.

Di dalam referensi atau acuannya memiliki dua macam referensi dalam kohesi gramatikal yaitu pengacuan endoforis dan eksoforis. Berdasarkan arah acuannya, pengacuan endoforis dibedakan menjadi pengacuan anaforis dan kataforis (Halliday dan Hasan dalam Hartono,

2012:110). Adapun pengacuan endoforis bersifat tekstual dan pengacuan eksoforis bersifat situasional, ialah sebagai berikut.

a) Pengacuan Endoforis

Pengacuan endoforis adalah pengacuan dalam teks atau pengacuan pada referen yang ada di dalam teks (Arifin dkk., 2018:26). Yang digunakan sebagai alat pengacu pada pengacuan endoforis ialah pronomina persona, pronomina demonstratif, ataupun komparatif. Contoh kalimatmya ialah :

A : Kemarin saya membeli beberapa buah buku baru. Akan tetapi, buku itu baru saya baca sebagian.

Frasa buku itu pada kalimat kedua mengacu pada objek beberapa buah buku yang ada di dalam teks pada kalimat pertama yang menjadi antesedennya. Anteseden adalah unsur yang mendahului atau yang mengikuti yang diacu oleh kata atau ungkapan dalam suatu klausa atau kalimat.

b) Pengacuan Eksoforis

Pengacuan eksoforis adalah pengacuan yang menunjuk ke sesuatu di luar teks.Contohnya pada kalimat berikut ini:

A : Barang siapa yang mencuri dan mengambil hak orang lain tanpa izin harus dihukum.

B : Siapa pun yang korupsi harus dihukum.

Barangsiapa dan siapa pun pada contoh di atas tidak mengacu ke sesuatu yang ada di dalam teks (tidak ada nomina apapun yang diacukannya dalam teks itu) tetapi menunjuk ke sesuatu di luar teks, yaitu orang mana pun yang membaca kalimat itu.

\section{2) Konjungtor atau Penghubung}

Konjungtor (kata sambung) adalah bentuk atau satuan kebahasaan yang berfungsi untuk menyambung, merangkai, atau menghubungkan kata dengan kata, frasa dengan frasa, klausa dengan klausa, kalimat dengan kalimat dan seterusnya (Kridalaksana dalam Arifin, dkk., 2018:61). Konjungtor disebut juga sarana perangkai unsur wacana, konjungtor juga amat mudah dikenali menjadi pemarkah formal. Beberapa jenis konjungtor antara lain konjungtor adversatif (misalnya: namun, tetapi), konjungtor kausal (misalnya: sebab, karena), konjungtor korelatif (misalnya: apalagi, demikian juga), konjungtor subordinatif (misalnya: meskipun, kalau), dan konjungtor temporal (misalnya: sebelumnya, sesudahnya, lalu, kemudian).

\section{3) Substitusi atau Pergantian}

Subsititusi (pergantian) adalah proses dan hasil penggantian unsur bahasa oleh unsur lain dalam satuan yang lebih besar. Penggantian ini dilakukan untuk memperoleh unsur pembeda atau untuk menjelaskan struktur tertentu (Kridalaksana dalam Arifin, dkk., 2018:62). Substitusi merupakan hubungan gramatikal, dan lebih bersifat hubungan kata dan makna. Contoh kalimat substitusi :

A : Rasa hormat dan ucapan terima kasih yang tulus penulis sampaikan kepada Bapak A dan Bapak B yang telah rela menolong ketika saya dalam kesulitan. Atas bantuan beliau berdua (Bapak berdua), saya dapat menyelesaikan pekerjaan itu dengan baik.

Frasa beliau berdua (Bapak berdua) pada kalimat itu merupakan bentuk yang menggantikan unsur lain yang telah disebutkan, yaitu Bapak A dan Bapak B. Penggantian itu menyebabkan kalimat tersebut berkaitan secara kohesif.

\section{4) Elipsis atau Pelesapan}

Pelepasan (elipsis) adalah salah satu jenis kohesi gramatikal yang berupa penghilang atau pelepasan satuan lingual tertentu yang telah disebutkan sebelumnya (Sumarlam, 2009:30). Pelesapan atau penghilangan adalah proses melesapkan bagian tertentu (kata atau satuan kebahasaan lainnya) di dalam kalimat, bentuk atau unsur yang dilesapkan itu dapat diperkirakan wujudnya, melalui konteks bahasa atau konteks luar bahasa (Kridalaksana dalam Arifin, dkk., 2018:63). Elipsis bisa juga merupakan pergantian unsur kosong (zero), yaitu unsur yang sebenarnya ada tetapi sengaja dihilangkan atau dilesapkan. Tujuan penggunan elipsis ialah untuk memperoleh kepraktisan berbahasa, yaitu agar bahasa yang digunakan lebih singkat, padat, dan dapat dimengerti dengan cepat. Jadi elipsis digunakan untuk efektivitas dan efisiensi berbahasa.

Berdasarkan pernyataan pendapat tersebut bahwa dalam wacana bagian kalimat yang sering dilesapkan ialah bagian subjek atau predikatnya. Contohnya pada kalimat berikut ini ;

A : Ya Allah, terima kasih Engkau telah memberi ku lebih dari apa yang aku minta. Engkau kuatkan dan sabarkan aku ketika (aku) dalam kesulitan sehingga aku dapat mengatasinya. Terima kasih ya, Allah atas.... Kalimat ketiga, "Terima kasih, ya Allah ...." merupakan kalimat elipsis, 
kalimat itu muncul karena penulis itu yakin bahawa Allah telah memberikannya lebih dari apa yang dimintanya, telah memberikannya kekuatan dan kesabaran kepadanya. Unsur yang dilespkan ialah subjek dan predikat .

\section{Teks Eksposisi}

Karangan eksposisi merupakan wacana yang bertujuan untuk memberi tahu, mengupas, menguraikan atau menerangkan sesuatu (Finoza, 2007:224). Berdasarkan pengertian tersebut, dapat diketahui bahwa karangan eksposisi merupakan salah satu jenis karangan atau tulisan yang menginformasikan sesuatu kepada pembaca dengan cara menguraikan dan menerangkannya secara lebih jelas. Karangan eksposisi karangan dengan tulisan yang menginformasikan suatu peristiwa baik menerangkan dengan memberikan gagasan dan informasi kepada pembaca.

Menurut Tedjo (2006:42) karangan eksposisi adalah suatu bentuk wacana yang berusaha menguraikan suatu objek sehingga memperluas pandangan atau pengetahuan pembaca. Objek yang diuraikan dalam karangan eksposisi merupakan suatu hal yang dapat bermanfaat bagi pembaca sehingga jika suatu hal tersebut disampaikan kepada pembaca, maka akan menambah pengetahuan, pandangan dan wawasan pembaca. Objek yang diterangkan dalam karangan eksposisi misalnya mengenai teknologi, perekonomian, kebudayaan, pertanian dan lain-lain. Objek tersebut diterangkan oleh penulis dengan cara diuraikan dan dipaparkan secara lengkap sehingga pembaca dapat memahami objek dengan lebih jelas. Karangan eksposisi ialah tulisan yang bertujuan memberikan informasi, menjelaskan, dan menjawab pertanyaan apa, mengapa, kapan, dan bagaimana (Semi, 2007:61).

Dari pengertian beberapa pakar di atas, dapat disimpulkan bahwa teks eksposisi merupakan salah satu jenis karangan atau tulisan yang menginformasikan sesuatu kejadian atau objek dalam bentuk teks. Objek yang diuraikan dalam karangan eksposisi merupakan suatu hal yang dapat bermanfaat bagi pembaca sehingga jika suatu hal tersebut disampaikan kepada pembaca, maka akan menambah pengetahuan, pandangan dan wawasan pembaca. Teks eksposisi dapat menjawab rasa ingin tahu pembaca tentang sesuatu yang dijelaskan melalui karangan eksposisi tersebut yang bertujuan untuk menjelaskan atau menyampaikan informasi disertai dengan ajakan agar pembaca dapat memahaminya.

\section{E. Hasil Temuan}

Sumber data dalam penelitian ini, yaitu menggunakan teks eksposisi siswa kelas X SMK Bina Budi Luhur Bogor sebanyak 30 teks. Dengan data penelitiannya yaitu Penggunaan wacana kohesi gramatikal (gramatikal substitusi, konjungtor, elipsis dan endoforis, eksoforis).

TABEL 1. Data Judul Teks Eksposisi Siswa

\begin{tabular}{clc}
\hline No. & \multicolumn{1}{c}{ Nama Siswa } & $\begin{array}{c}\text { Judul Teks Eksposisi } \\
\text { Siswa }\end{array}$ \\
\hline 1. & $\begin{array}{l}\text { Muhammad Anggi } \\
\text { Syaputra }\end{array}$ & $\begin{array}{l}\text { Menjaga Kebersihan } \\
\text { Lingkungan Sekolah }\end{array}$ \\
\hline
\end{tabular}

\begin{tabular}{|c|c|c|}
\hline No. & Nama Siswa & $\begin{array}{c}\text { Judul Teks Eksposisi } \\
\text { Siswa } \\
\end{array}$ \\
\hline 2. & Annisa Zulianthy & $\begin{array}{l}\text { Kesehatan Tubuh dengan } \\
\text { Mengonsumsi Buah dan } \\
\text { Sayur }\end{array}$ \\
\hline 3. & Aliv & $\begin{array}{l}\text { Stop Kekerasan pada } \\
\text { Anak }\end{array}$ \\
\hline 4. & Zulfa Nabila & Kemacetan Lalu Lintas \\
\hline 5. & Syahrial Ariza & Pandemi Global \\
\hline 6. & M. Althaf Nasrallah & $\begin{array}{l}\text { Mencuci Tangan dengan } \\
\text { Sabun Efektif Cegah } \\
\text { Covid-19 }\end{array}$ \\
\hline 7. & Fani Agustiana & Gempa Bumi \\
\hline 8. & $\begin{array}{l}\text { Mohamad Ikhsan } \\
\text { Kamil }\end{array}$ & Manfaat Wortel \\
\hline 9. & Shadam & $\begin{array}{l}\text { Pembangunan dan } \\
\text { Bencana Alam }\end{array}$ \\
\hline 10. & Nia Nurmalasari & $\begin{array}{l}\text { Kelebihan dan Kerugian } \\
\text { Internet }\end{array}$ \\
\hline 11. & Ari Hidayat & $\begin{array}{l}\text { Jangan Pilih Kepala } \\
\text { Daerah yang Tidak } \\
\text { Ramah terhadap Alam }\end{array}$ \\
\hline 12. & $\begin{array}{l}\text { Muhammad } \\
\text { Suhendar }\end{array}$ & $\begin{array}{l}\text { Menjaga Kesehatan Mata } \\
\text { Depan Komputer }\end{array}$ \\
\hline 13. & Septi Wulandari & $\begin{array}{l}\text { Manfaat Lidah Buaya } \\
\text { Bagi Manusia }\end{array}$ \\
\hline 14. & Peni Ariyanti & $\begin{array}{l}\text { Olahraga untuk } \\
\text { Kesehatan Tubuh }\end{array}$ \\
\hline 15. & Indri Aulia Safitri & Pemanasan Global \\
\hline 16. & Rukmini & Cara Menghindari Polusi \\
\hline 17. & Silvani & Manfaat Jamu Tradisional \\
\hline 18. & Syahrul Fauzian & Terjadinya Gempa Bumi \\
\hline 19. & Nia Aulia & Bencana Banjir \\
\hline 20. & Banny Audzan & $\begin{array}{l}\text { Membuang Sampah di } \\
\text { Sungai Menyebabkan } \\
\text { Lingkungan Tercermar }\end{array}$ \\
\hline 21. & $\begin{array}{l}\text { Ahmad Zaenal } \\
\text { Ambya }\end{array}$ & $\begin{array}{l}\text { Belajar di Era Pandemi } \\
\text { Covid-19 }\end{array}$ \\
\hline 22. & Syahwa Hermalina & Kesehatan Mata \\
\hline 23. & Indri Herlinda & Sampah Rumah Tangga \\
\hline 24. & Siti Noviyanti & $\begin{array}{l}\text { Pacaran Sebagai Gaya } \\
\text { Hidup Remaja }\end{array}$ \\
\hline 25. & Bunga Sabila & $\begin{array}{l}\text { Anggota DPR Malas } \\
\text { Memikirkan Rakyat }\end{array}$ \\
\hline 26. & Mardiono & $\begin{array}{l}\text { Memelihara Kebersihan } \\
\text { Lingkungan Rumah }\end{array}$ \\
\hline 27. & Intan Stf Suriyani & Teknologi Tepat Guna \\
\hline 28. & Lusi Sutiawati & $\begin{array}{l}\text { Pemanasan Global dan } \\
\text { Hilangnya Hutan } \\
\text { Lindung }\end{array}$ \\
\hline 29. & Sri Rahayuningsih & $\begin{array}{l}\text { Pembelajaran Jarak jauh } \\
\text { Kurang Efektif }\end{array}$ \\
\hline
\end{tabular}




\begin{tabular}{lll}
\hline No. & \multicolumn{1}{c}{ Nama Siswa } & \multicolumn{1}{c}{$\begin{array}{c}\text { Judul Teks Eksposisi } \\
\text { Siswa }\end{array}$} \\
\hline 30. & Nurul Aurelia & $\begin{array}{l}\text { Pentingnya Pendidikan } \\
\text { Karakter di Sekolah }\end{array}$ \\
\hline
\end{tabular}

Alat kohesi gramatikal merupakan alat dalam penggunaan bentuk kata pada kalimat atau wacana. Dalam penelitian ini, ada lima alat kohesi yang ditemukan, yaitu referensi endoforis, referensi eksoforis, konjungtor, substitusi, dan elipsis. Lima alat tersebut ditemukan dalam beberapa teks eksposisi hasil karya siswa kelas X SMK Bina Budi Luhur Bogor.

Alat kohesi gramatikal referensi endoforis sering ditemukan pada pengacuan lingual yang satu dengan lingual yang lainnya baik itu pengacuan yang terjadi pada suatu bagian kalimat, kata atau frasanya. Kata acuan yang ditemukan ialah salah satunya sebagai berikut kata buah ini yang mengacu pada kalimat sebelumnya, yaitu buah alpukat. Kalimat buah ini mengacu pada kalimat yang telah disebut sebelumnya, yaitu buah alpukat yang ada di dalam teks yang tentunya menjadi entesedennya. Entesedennya, yaitu unsur mendahului atau mengikuti yang diacu oleh kata atau ungkapan dalam sebuah kalimat. Contoh lainnya ialah pada kalimat penyakit ini yang mengacu pada kalimat sebelumnya, yaitu covid-19. Artinya penyakit ini yang disebut dalam kalimat kedua yang ada dalam teks tersebut ialah covid-19 yang diacu atau disebut di kalimat sebelumnya.

Alat kohesi gramatikal referensi eksoforis ditemukan juga dalam penggunaannya pada hasil teks eksposisi siswa yang dibuat. Penulis telah menemukan pada beberapa teks eksposisi siswa yang menggunakan referensi eksoforis seperti siapapun, seluruh negara, orang lain dan lainnya. Referensi eksoforis mengacu pada acuan sesuatu yang berada di luar teks.

Pada penulisan kalimat, siswa dituntut untuk menulis dengan kata yang baik dan benar sehingga ditemukan banyak alat kohesi gramatikal berupa konjungtor. Penggunaan alat kohesi ini diketahui dengan menghubungkan unsur yang satu dengan unsur yang lain dalam sebuah wacana atau kalimat. Unsur yang dirangkaikan atau dihubungkan dapat berupa satuan lingual kata, frasa, klausa, kalimat dan dapat berupa unsur yang lebih besar dari itu. Penulis juga menemukan banyak penggunaan alat kohesi gramatikal berupa konjungtor, yaitu apalagi, karena, namun, tetapi, sehingga, meskipun dan masih banyak lagi.

Adapun dalam penggunaan alat kohesi gramatikal berupa substitusi dan elipsis ditemukan beberapa penggunaannya dalam teks yang ditulis oleh siswa. Substitusi merupakan pergantian suatu unsur bahasa oleh unsur lain dalam satuan yang lebih besar. Contohnya penulis menemukan kata mereka untuk menggantikan kata yang merujuk sebelumnya ialah RT, Bapak-bapak, Ibu atau bahkan anak-anak agar kata menjadi lebih efektif.

Sedangkan elipsis ialah pelesapan atau penghilangan bagian tertentu agar kata atau kalimat lebih efektif. Ditemukan juga beberapa data dalam penggunaan kohesi gramatikal elipsis salah satunya ialah kalimat ayo kurangi seharusnya ditulis ayo kita kurangi mengingat kata sebelumnya ialah (kita) ikut andil dalam masalah kemacetan lalu lintas. Tetapi untuk menghindari pengulangan kata yang mubazir maka hanya ditulis ayo kurangi dan kata kita dilesapkan. Oleh karena itu, lima alat kohesi gramatikal sangat dibutuhkan dalam penulisan sebuah paragraf agar pembaca tidak bosan serta dapat mengikuti irama yang efektif dalam paragraf tersebut.

Hasil analisis data penggunaan alat kohesi gramatikal pada teks eksposisi siswa kelas X SMK Bina Budi Luhur Bogor yang telah dipaparkan, dapat dilakukan perhitungan persentase dari hasil analisis penggunaan alat kohesi gramatikal tersebut untuk mengetahui alat kohesi gramatikal yang paling dominan. Perhitungan tersebut dilakukan dengan cara sebagai berikut:

\section{Rumus Persentase \\ $=\frac{\text { Jumlah yang didapat }}{\text { Jumlah seluruh data yang dianalisis }} \times 100$}

TABEL 2. Hasil Analisis Data Kohesi Gramatikal

\begin{tabular}{clcc}
\hline No & \multicolumn{1}{c}{$\begin{array}{c}\text { Kohesi } \\
\text { Gramatikal }\end{array}$} & Jumlah & Persentase \\
\hline 1. & Refesensi & 44 & $29 \%$ \\
& Endoforis & & \\
2. & Referensi Eksoforis & 25 & $17 \%$ \\
3. & Konjungtor & 60 & $40 \%$ \\
4. & Substitusi & 14 & $9 \%$ \\
5. & Elipsis & 7 & $5 \%$ \\
& Jumlah & 150 & $100 \%$ \\
\hline
\end{tabular}
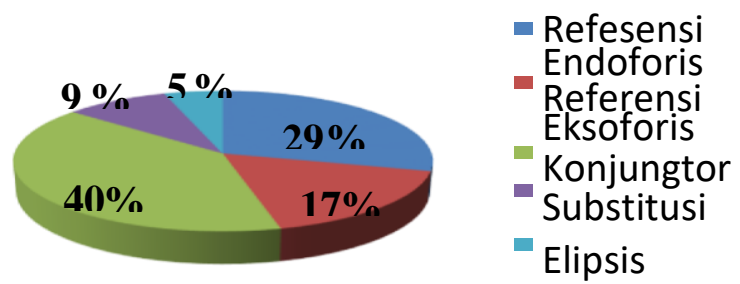

\section{GAMBAR 1. Penggunaan Kohesi Gramatikal Pada Teks Eksposisi Siswa}

Berdasarkan tabel di atas, dapat diketahui berapa banyak penggunaan alat kohesi gramatikal pada teks eksposisi siswa kelas X SMK Bina Budi Luhur Bogor. Hasil penelitian ini akan diuraikan hasil analisis penggunaan alat kohesi gramatikal pada teks eksposisi siswa kelas X SMK Bina Budi Luhur Bogor dengan jumlah data yang telah dianalisis. Berdasarkan data di atas, dari jumlah keseluruhan penggunaan alat kohesi gramatikal, yaitu sebanyak 150 data yang telah dianalisis, ditemukan penggunaan referensi endoforis sebanyak 44 data yang dipersentasekan menjadi $29 \%$, kemudian penggunaan referensi eksoforis sebanyak 25 data yang dipersentasekan menjadi $17 \%$, lalu penggunaan 
konjungtor sebanyak 60 data yang dipersentasekan menjadi $40 \%$, berikutnya penggunaan substitusi sebanyak 14 data yang dipersentasekan menjadi $9 \%$, dan yang terakhir penggunaan elipsis sebanyak 7 data yang dipersentasekan menjadi $5 \%$.

Berdasarkan hasil analisis pada teks eksposisi siswa terdapat 150 data penggunaan alat kohesi gramatikal. Hasil analisis menunjukkan bahwa penggunaan alat kohesi gramatikal terbanyak, yaitu penggunaan konjungtor sebanyak 60 data. Kemudian jumlah yang sedang, yaitu penggunaan referensi endoforis sebanyak 44 data. Dan penggunaan alat kohesi gramatikal yang paling sedikit digunakan adalah alat kohesi gramatikal berupa elipsis dengan jumlah temuan sebanyak tujuh data.

Adapun berkenaan dengan hasil analisis penggunaan alat kohesi gramatikal yang meliputi referensi endoforis, referensi ekoforis, konjuntor, subtitusi, dan elipsis. Dapat disimpulkan bahwa penggunaan alat kohesi gramatikal yang paling dominan pada teks eksposisi siswa kelas X SMK Bina Budi Luhur Bogor terdapat pada penggunaan alat kohesi gramatikal berupa konjungtor dengan temuan data 60 kutipan dengan persentase $40 \%$.

\section{KESIMPULAN}

Berdasarkan hasil analisis dan pembahasan mengenai penggunaan jenis alat kohesi gramatikal dalam teks eksposisi siswa kelas X SMK Bina Budi Luhur Bogor dapat disimpulkan bahwa hasil penelitian pada alat kohesi gramatikal ditemukan lima jenis alat, yang pertama adalah alat kohesi gramatikal berupa referensi endoforis ditemukan pada pengacuan lingual yang satu dengan lingual yang lainnya baik itu pengacuan yang terjadi pada suatu bagian kalimat, kata atau frasanya. Kata acuan yang ditemukan ialah salah satunya sebagai berikut kata buah ini yang mengacu pada kalimat sebelumnya, yaitu buah alpukat. Contoh lainnya ialah pada kalimat penyakit ini yang mengacu pada kalimat sebelumnya, yaitu covid-19.

Selanjutnya yang kedua, kata siapapun, seluruh negara, orang lain dan lainnya termasuk pada alat kohesi gramatikal berupa referensi eksoforis. Ketiga, yaitu alat kohesi gramatikal berupa konjungtor seperti; apalagi, karena, namun, tetapi, sehingga, meskipun dan masih banyak lagi. Keempat, alat kohesi gramatikal berupa substitusi seperti kata mereka untuk menggantikan kata yang merujuk sebelumnya ialah RT, Bapak-bapak, Ibu atau bahkan anak-anak agar kata menjadi lebih efektif, dan yang kelima ialah alat kohesi gramatikal berupa elipsis penghilangan bagian tertentu agar kata atau kalimat lebih efektif salah satunya ialah kalimat ayo kurangi seharusnya ditulis ayo kita kurangi mengingat kata sebelumnya ialah (kita) ikut andil dalam masalah kemacetan lalu lintas. Oleh karena itu, kelima jenis alat kohesi gramatikal ini sangat dibutuhkan dalam penulisan sebuah paragraf dalam teks agar pembaca tertarik dan tidak bosan serta dapat mengikuti kepaduan dari isi teks tersebut.

Kemudian, hasil analisis menunjukkan bahwa penggunaan jenis alat kohesi gramatikal terbanyak yaitu penggunaan konjungtor sebanyak 60 data yang dipresentasekan menjadi 40\%. Jadi, dengan mencermati hasil analisis penggunaan alat kohesi gramatikal dalam teks eksposisi siswa tersebut dapat diketahui bahwa yang paling banyak digunakan oleh siswa dalam membuat teks eksposisi ialah alat kohesi gramatikal berupa konjungtor untuk lebih padu. Hal ini dimungkinkan karena pengetahuan siswa terhadap penggunaan alat kohesi gramatikal dalam membuat teks eksposisi masih mengalami keterbatasan, hanya penggunaan kata hubung saja yang rata-rata mereka ketahui. Adapun dari hasil temuan tersebut dapat menambah wawasan secara luas mengenai kohesi gramatikal di dalam ruang lingkup pembelajaran di kelas ataupun di dalam kehidupan sehari-hari, karena kohesi gramatikal banyak digunakan dalam wacana secara lisan maupun tulisan berbentuk teks.

\section{REFERENSI}

Arifin, Zaenal dkk. (2018). Wacana Transaksional dan Interaksional. Jakarta: Pustaka Mandiri.

Eka, Desi. (2016). Kohesi Gramatikal dalam Teks Berita Media Massa Cetak. Lingua: Kohesi Gramatikal.

Hafish, Fandy. (2015). Kohesi Gramatikal antar Kalimat dalam Wacana. Lingua: Journal Kohesi Gramatikal. 9-29.

Kosasih, E. (2014). Jenis-jenis Teks: Analisis Fungsi, Struktur, Kaidah Kebahasaan, serta Langkahlangkah Penulisannya. Bandung. Yrama Widya.

Mahsun. (2014). Teks dalam Pembelajaran Bahasa Indonesia Kurikulum 2013. Jakarta. Rajagrafindo Persada.

Mulyana. (2005). Kajian Wacana: Teori, Metode dan Aplikasi Prinsip-Prinsip Analisis Wacana. Yogyakarta. Tiara Wacana.

Rusminto, Nurlaksana Eko. (2015). Analisis Wacana; Kajian Teoritis dan Praktis. Yogyakarta. Graha Ilmu.

Rosmaya, Elin. (2018). Pembelajaran Menulis Teks Eksposisi dengan Menggunakan Pendekatan Kooperatif Tipe Investigasi Kelompok di SMP. Lingua: Journal Teks Eksposisi.

Sumarlan. (2009). Teori dan Praktik Analisis Wacana. Surakarta. Pustaka Cakra.

Syamsuddin. (2011). Studi Wacana: Teori Analisis dan Pengajaran. Bandung. Geger Sunten.

Tarigan, Henry Guntur. (2009). Pengajaran Wacana. Bandung: Angkasa.

Wiyanti, Endang. (2016). Kajian Kohesi Gramatikal Substitusi dan Elipsis dalam Novel Laskar Pelangi Karya Andrea Hirata. Lingua: Journal Kohesi Gramatikal. 